\title{
Influence of Thermal Comfort on Health
}

\begin{abstract}
CARMEN OTILIA RUSANESCU1, MARIN RUSANESCU2*, COSMIN J INESCU ${ }^{3 *}$, GIGEL PARASCHIV ${ }^{1}$
${ }^{1}$ University Polytechnic, Faculty of Biotechnical Systems Engineering, 313 Splaiul Independentei, 060042 Bucharest, Romania

2Valplast Industrie 9 Preciziei Blv., 062202, Bucharest, Romania

${ }^{3 *}$ Politehnica University of Bucharest, Faculty of Mechanical Engineering, 313 Splaiul Independentei , 060042, Bucharest, Romania

The purpose of this paper is to estimate the conditions of human comfort in Bucharest. To describe the influence of the climate on human health, several indices have been developed describing the degree of physiological comfort offered by the meteorological conditions, taking into account meteorological parameters registered daily by the weather station at the Polytechnic University of Bucharest, Faculty of Biotechnical Systems Engineering: temperature and relative air humidity, wind speed. The following indices were analyzed: summer SCHARLAU index (ISE), winter SCHARLAU index (ISH), thermohigrometric index $(T H I)$, wind cooling power (skin stress index) $(P)$, temperature equivalent to cooling wind power $T_{p, r}$ to determine the influence of thermal comfort on health.
\end{abstract}

Keywords: thermal comfort indices, wind cooling power

Climate has a directimpact on people's lives and health. The measured values of the meteorological parameters are perceived differently by the human body due to the particular physical condition of the persons and the weather conditions. Depending on the air temperature, the wind may cool, suffocate or dull. It is necessary to know the limitations imposed by bioclimate on the human body, from a practical and theoretical point of view [4]. The analysis of the evolution and distribution of atmospheric parameters impacting the human body is of interest to the capital city of Bucharest with a population of approximately 1884 million inhabitants. Knowledge particularities bioclimatic of Bucharest is fully justified, even if we refer only to the significant number of people living in this region as well as tourists, under the specific bioclimatic conditions.

To describe the influence of thermal comfort on human health, several indexes have been developed describing the degree of physiological comfort offered by the meteorological conditions, taking into account different parameters (relative air temperature and relative humidity, wind velocity) as measured by weather station sensors from Politehnica University of Bucharest, Faculty of Biotechnical Systems Engineering, sensors made of corrosion resistant materials in accordance with environmental legislation [7, 10, 12, 16-18, 26-29, 31, 32, 33]. Climate conditions influence the comfort of organisms [22]. All organisms, including humans, it adapts in time to climatic conditions, but the variation or tendencies of increasing and decreasing certain parameters can induce additional stress. To highlight the climate favorability in Bucharest, bioclimatic indices were analyzed: summer SCHARLAU index (ISE), winter SCHARLAU index (ISH), thermohigrometric index (THI), wind cooling power (cutaneous stress index), the temperature equivalent to the cooling wind power $T$.

The climate is favorable to the activities throughout the year. The summer sun during the cold period causes excessive heat (sunstroke, hyperthermia, dehydration), sometimes associated with other associated side effects such as urinary or renal infections caused by insufficient hydration or excess water renal elimination. Ultraviolet radiation can cause: melanoma, eye disease (cataracts), sunstroke, sunburn. When the thermometer getdown under
-4 degrees Celsius, the risk of heart attack increases. The cold is also dangerous for people suffering from respiratory failure. Defects occur when exposure to low air temperatures. Hypothermia builds up after prolonged exposure to cold when body temperature falls below the threshold of minimally admitted domestic $\left(-37^{\circ} \mathrm{C}\right)$. In this situation, the body begins to react violently: chills get maximum intensity. Pulmonary diseases have a higher degree of occurrence in autumn and winter when relative humidity exceeds $50 \%$ and wind speed is lower. Also during this period there are sudden cooling associated with the decrease of the atmospheric pressure. The most common disease is the cold that occurs due to the low immunity of the body. Flu and influenza is common in September, with a peak occurring in the winter months (December). Pneumonia usually occurs due to sudden heating in the cold season.

\section{Experimental part}

Materials and methods

Summer SCHARLAU Index (ISE)

The summer Scharlau index describes a bioclimatic thermal comfort when temperature values are higher than $0^{\circ} \mathrm{C}$, as the values decrease, the more intensive the heat discomfort (table 1). Calculation of summer SCHARLAU is achieved by considering that at a certain critical value of relative humidity corresponds to a critical limit value of air temperature over which, in the absence of wind, the human body begins to feel the feeling of discomfort by heating due to unfavorable bioclimatic conditions (wet heat) [13].

The summer Scharlau index can only be calculated for relative humidity values higher than $30 \%$ and air temperature between $+17^{\circ} \mathrm{C}$ and $+39^{\circ} \mathrm{C}$. Temperatures below $+17^{\circ} \mathrm{C}$ describe a relative bioclimatic comfort state, and higher than $+39^{\circ} \mathrm{C}$, cause an increased discomfort $[3,4]$.

For the calculation For the SCHARLAU estival (ISE), calculate the appropriate critical temperature $\left(T_{c}\right)$ value according to the logarithmic equation:

$$
T_{c}=[-17,089 * \operatorname{Ln}(U)]+94.979
$$

\footnotetext{
* email: rusanescum@yahoo.com, cosmin.jinescu@yahoo.com
} 
where: $\mathrm{T}_{c}$ critical temperature $\left({ }^{\circ} \mathrm{C}\right) ; \mathrm{U}$ relative air humidity (\%)

The summer SCHARLAU (ISE) value (expressed in units) is given by the difference between the critical temperature $\left(T_{C}\right)$ and the local temperature (air temperature measured on the dry thermometer) $\left(T_{\text {usc }}\right)$ :

$$
\text { ISE }=T_{c}-T_{a}
$$

This temperature difference can be: positive when the local temperature does notexceed the critical temperature, there is no discomfort; negative when the local temperature exceeds the critical temperature, causing discomfort by heating [30].

The Scharlau index has two variants: the Summer Scarlau Index (ISE) and the Winter Scharlau Index (ISH) [5].

Table 1

THE SUMMER SCHARLAU INDEX -ISE (UNITS) AND CRITICAL TEMPERATURES $\left({ }^{\circ} \mathrm{C}\right)[5]$

\begin{tabular}{|c|c|}
\hline $\begin{array}{c}\text { Summer Scharlau } \\
\text { Index ISE }\end{array}$ & Bioclimatic stress \\
\hline ISE $\geq 0$ & Comfort bioclimatic \\
\hline$-1<$ ISE $<0$ & Easy discomfort \\
\hline$-3-$ ISE $\leq-1$ & Moderate discomfort \\
\hline ISE $\leq-3$ & Strong discomfort \\
\hline
\end{tabular}

\section{SCHARLAU winter index (ISH)}

Reflects the level of human discomfort caused by cooling. Associated critical temperatures are the corresponding air temperature values below which, in the absence of wind, the human body feels discomfort due to cooling due to unfavorable bioclimatic conditions (wet cold) [5]. The Scharlau hibernal index can only be calculated for relative humidity values higher than $40 \%$ and air temperature between $-5^{\circ} \mathrm{C}$ and $+6^{\circ} \mathrm{C}$. Temperatures above $+6^{\circ} \mathrm{C}$ describe a relative bioclimatic comfort state, and the lowest of $-5^{\circ} \mathrm{C}$, create a state of discomfort [3].

For calculating the SCHARLAU Hybernal Index (ISH), the corresponding critical temperature $\left(T_{c}\right)$ value must be calculated according to equation:

$$
T_{c}=(0.0003 * U)+(0,1497 * U)-7.7133
$$

where: $\mathrm{U}$ - relative air humidity (\%); Tc - critical temperature $\left({ }^{\circ} \mathrm{C}\right)$

The winter SCHARLAU (ISH) (expressed in units) is calculated by the difference betw een air temperature and critical temperature (Tc), according to the relationship (4):

$$
\mathrm{ISH}=\mathrm{T}_{\mathrm{a}}-\mathrm{T}_{\mathrm{c}}
$$

This temperature difference can be: positive when the local temperature is higher than the critical temperature, which does not cause discomfort, negative when the local temperature is lower than the critical temperature, which causes cooling discomfort. The classes of values corresponding to the Winter Scharlau index are shown in table 2.
Table 2

VALUE CLASSES FOR ISH $[3,5]$

\begin{tabular}{|c|c|}
\hline ISH & Type of discomfort \\
\hline ISH $\geq 0$ & Comfort \\
\hline$-1<\mathrm{ISH}<0$ & Easy discomfort \\
\hline$-3<\mathrm{ISH} \leq-1$ & Moderate discomfort \\
\hline ISH $\leq-3$ & Strong discomfort \\
\hline
\end{tabular}

\section{Thermohygrometric index (THI)}

THI is calculated based on air temperature and relative humidity. The formula used to determine this index is $[6,8$, 9, 11]:

$$
\text { THI }[p C]=T_{\text {usc }}-(0.55-0.0055 * U R) *\left(T_{\text {usc }}-14.5\right)
$$

where: Air temperature $\left[{ }^{\circ} \mathrm{C}\right]$ to dry thermometer; UR relative humidity [\%].

Using this index can be classified conditions and types of climate, for hot and cold weather [11].

\begin{tabular}{|c|c|}
\hline Temperature, [0C] & THI category \\
\hline$<-40$ & Hyper-glacial \\
\hline-39.9 to -20 & Glacial \\
\hline-19.9 to -10 & Excessive cold \\
\hline-9.9 to -1.8 & Very cold \\
\hline-1.7 to 12.9 & Cold \\
\hline 13 to 14.9 & Cool \\
\hline 15 to 19.9 & Comfort \\
\hline 20 to 26.4 & Hot \\
\hline 26.5 to 29.9 & Very hot \\
\hline$>30$ & Heat \\
\hline
\end{tabular}

Table 3

THRESHOLDS OF THI VALUES FOR DIFFERENT TYPES OF BIOCLIMATES [14, 15]

\section{Wind Cooling Power (Skin Stress Index)}

The human body, through its exposed parts (skin), comes in direct contact with the terrestrial atmosphere whose parameters (brightness, radiation, temperature, humidity, wind) require it to adapt to the meteo-climatic complex by triggering thermolysis or thermogenesis. In some situations thermoregulation is not required.

In 1974, Becancenot, the wind cooling power formula that takes into account two weather-climatic parameters: air temperature and wind speed. It is a meteorophysiological concept that expresses in objective terms the combined action of air temperature and wind speed on the caloric balance of the human body. The calculation formula for the wind cooling power is:

$$
P=(10 \sqrt{v}+10,45-v) \cdot(33-t)
$$

where: $P$ the cooling power $\left[\mathrm{kcal} / \mathrm{m}^{2} / \mathrm{h}\right]$, v the wind speed $[\mathrm{m} / \mathrm{s}]$, the air temperature conventionally reported at the $33\left[{ }^{\circ} \mathrm{C}\right]$. Values of wind cooling power, assigned to classes, have been determined, depending on the reactions of the human body, with indices of comfort or discomfort with different values and signs (negative, null or positive). These are called cutaneous stress indexes. They return the 


\begin{tabular}{|l|l|l|l|}
\hline Cooling power [kcal $\left./ \mathrm{m}^{2} / \mathrm{h}\right]$ & $\begin{array}{l}\text { Indications of } \\
\text { skin stress }\end{array}$ & $\begin{array}{l}\text { The character } \\
\text { (meaning) }\end{array}$ & The type of stress \\
\hline $0-149$ & -2 & hypotonic & $\begin{array}{l}\text { stress by triggering thermolysis } \\
\text { during the summer }\end{array}$ \\
\hline $150-299$ & -1 & hypotonic & $\begin{array}{l}\text { stress by triggering thermolysis } \\
\text { during the summer }\end{array}$ \\
\hline $300-599$ & 0 & relaxing & not require thermoregulation \\
\hline $600-899$ & +1 & hypertonic & $\begin{array}{l}\text { Hypertonic stress by triggering } \\
\text { thermogenesis in winter }\end{array}$ \\
\hline $900-1199$ & +2 & hypertonic & $\begin{array}{l}\text { stress by triggering } \\
\text { thermogenesis in winter }\end{array}$ \\
\hline $1200-1499$ & +3 & hypertonic & $\begin{array}{l}\text { stress by triggering } \\
\text { thermogenesis in winter }\end{array}$ \\
\hline$>1500$ & +4 & hypertonic & $\begin{array}{l}\text { stress by triggering } \\
\text { thermogenesis in winter }\end{array}$ \\
\hline
\end{tabular}

Table 4

THE COOLING POWER OF THE WIND $\left[\mathrm{kcal} / \mathrm{m}^{2} / \mathrm{h}\right]$ AND THE SIGNIFICANCE OF THE BIOSTRESS INDEX SKIN [23]

\begin{tabular}{|l|l|l|}
\hline $\begin{array}{l}\text { Cooling power P } \\
{\left[\mathrm{W} / \mathrm{m}^{2}\right]}\end{array}$ & $\begin{array}{l}\text { Equivalent temperature of } \\
\text { cooling wind power } \mathrm{T}_{\mathrm{pr}}\left[{ }^{\circ} \mathrm{C}\right]\end{array}$ & Physiological effects \\
\hline $200-400$ & $\mathrm{Tpr}>+10$ & No discomfort \\
\hline $400-600$ & $+10 \geq \mathrm{Tpr}>-1$ & Easy discomfort \\
\hline $600-800$ & $-1 \geq \mathrm{Tpr}>-10$ & Strong discomfort \\
\hline $800-1000$ & $-10 \geq \mathrm{Tpr}>-18$ & Very cold \\
\hline $1000-1200$ & $-18 \geq \mathrm{Tpr}>-29$ & Hipocaloric stress \\
\hline $1200-1400$ & $-29 \geq \mathrm{Tpr}>-50$ & $\begin{array}{l}\text { Risk of frostbite under } \\
\text { prolonged exposure conditions }\end{array}$ \\
\hline 1400 & Tpr $\leq-50$ & Risk of instant frostbite \\
\hline
\end{tabular}

Table 5

THE COOLING POWER OF WIND, EQUIVALENT TO WIND COOLING POWER AND PHYSIOLOGICAL EFFECTS INDUCED BY IT [20] character of time / climate, but also the degree to which the human body is subjected to stress induced by the lower or higher values of the wind cooling power [19]. The wind cooling power $\left(\mathrm{kcal} / \mathrm{m}^{2} / \mathrm{h}\right)$ and the significance of the cutaneous biostress index is shown in table 4 [23] .

The temperature equivalent to wind cooling power $T$

The wind cooling power index is completed by the temperature equivalent to the wind cooling power $\mathrm{T}_{\mathrm{pr}}$. This is the temperature the air would reach at certain wind speeds. The calculation formula for $\mathrm{T}_{\mathrm{pr}}[20,25]$ is given by the relationship:

$$
T_{p r}=\left[33+\left(T_{u s c}-33\right)(0.474+0.454 \sqrt{v}-0,0454 v)\right]
$$

$\mathrm{T}$ temperature equivalent to cooling wind power $\left[{ }^{\circ} \mathrm{C}\right]$, $\mathrm{T}_{\text {usc }}$ áir temperature measured at dry thermometer $\left[{ }^{\circ} \mathrm{C}\right], \mathrm{v}$ wind speed [m/s].

The value ranges of $P$ correspond to intervals with certain values of $T_{p}$. The effects of $P$ (and related $T_{p r}$ ) on human physiology depend on the intensity of caloric losses suffered by the human body.

\section{Results and discussions}

\section{Summer SCHARLAU Index (ISE)}

In figure 1 are highlighted calculations of the SCHARLAU summer report.

By comparing the values obtained in figure 1 with the values in table 1, during J une, 2016, 2017, 2018, J uly 2010, 2011, 2017, 2018 and August 2018, values corresponding to the thermal comfort were obtained during most of the months values between -1 and -3 were recorded, indicating a moderate discomfort mainly due to an increase in evaporation rate that prevents the human body from eliminating excess heat inside so that the temperature of the inner body increases, creating discomfort due to overheating. August 2018 the discomfort class accentuated the value of -5.4 . The rest of the analyzed period with specific thermal comfort values.

\section{SCHARLAU winter index (ISH)}

Figure 2 highlights the calculations made for the winter SCHARLAU index.

Comparing the values obtained with those in table 2 during the analyzed period in most months, values corresponding to the increased discomfort (values less than or equal to -3) were obtained only in December 2011, 2015, 2016, 2017, February 2013, March 2018, November 2012 , 2014, values ranging from -1 to -3 units were recorded, indicating moderate discomfort.

\section{Thermohygrometric index (THI)}

According to the THI index thresholds (table 3 ) itcan be observed (fig. 3) that the corresponding values were obtained as: cold, in all the analyzed years in the months: March, November, December, January 2009, 2010, 2011, 2012 , 2013, 2014, 2015, 2016, 2018, February only February 2012 very cold in January 2017 and February 2012. Cones in April 2009, 2010, 2017, October 2009, 2012, 2017. Comfort in May in all years, April 2015 , 2016, 2018, June 2010, 2014, July 2013, September 2009, 2010, 2012, 2013, 2014, 2016, 2017, 2018, October 2018.

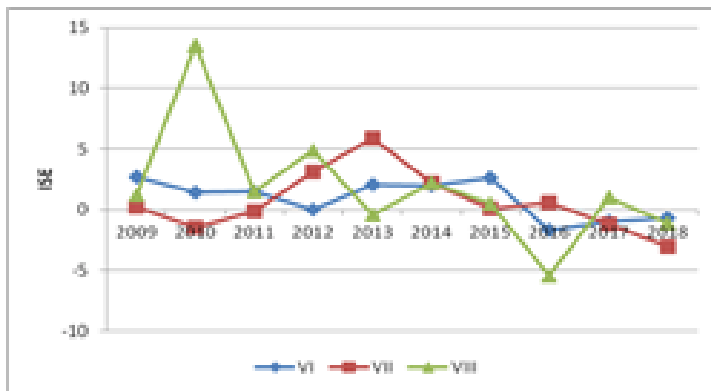

Fig. 1 Values obtained for ISE in 2009-2018

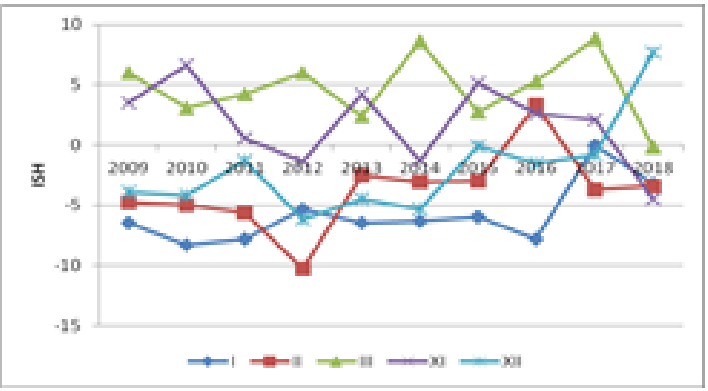

Fig. 2 Values obtained for ISH in 2009-2018 


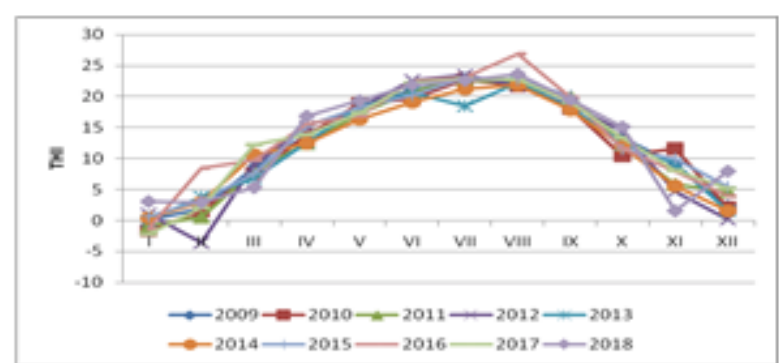

Fig. 3 Values obtained for THI in 2009-2018

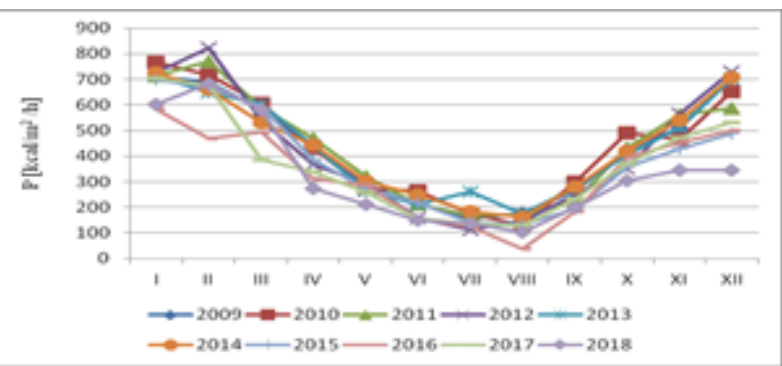

Fig. 4 Values obtained for $P$ in 2009-2018
From the analysis of the monthly average values of the THI index obtained on the basis of mathematical calculations, it can be easily observed that the analyzed region ranges between $-3.6^{\circ} \mathrm{C}$ (February 2012) and +26.9 ${ }^{\circ} \mathrm{C}$ August 2016. According to the annual averages, notes that the variation of the THI index is directly proportional to temperature rise or fall. The monthly average values of the THI index show that, as a whole, the city of Bucharest is maintained in a cold bioclimate, subjecting the human body to a higher calorie adaptation effort. In understanding the causality of some behavioral aspects, the climate plays an important role. Bioclimatic indicators have the role of highlighting the influence of climate on the human body. The exciting steppe climate, specific to Bucharest, forces the living organisms to adapt to low rainfall and very high temperatures through warm and dry summers. These adaptations take the form of a slight discomfort highlighted by the bioclimatic indices analyzed. Bioclimatic discomfort is reflected in the occurrence of cardiovascular and respiratory diseases, but also through behaviors characterized by intolerance, violence and impulsiveness.

\section{Wind Cooling Power (Skin Stress Index)}

I calculated the skin stress index of formula (6) according to the index analysis thresholds (table 4).

It is observed that during the summer the predominant values are between 150-299 corresponding to stress by triggering thermolysis, exerting on the human body a slight discomfort, which requires heat loss (eg perspiration), respectively thermolysis (fig. 5) May, August, all years analyzed: May 2009, 2010, 2012, 2013, 2015, 2016, 2017, 2018, July 2009, 2010, 2011, 2013, 2014, 2015, August 2009, 2011, 2013, 2014.

In the coldest months, J anuary, February, December, the decrease in skin stress is moderately hypertonic. Hypertonic stress by triggering thermogenesis in winter the values of the index are between 600-823 (fig. 4), January and February the analyzed period 2009-2018 less January and February 2016, December 2016, 2017, 2018.

In March 2009, 2011, 2012 and April 2009, 2010, 2011, 2012 , no thermoregulation is required.

The values are in the category of hypotonic stress, stress by triggering thermolysis in summer values between 101144, July 2010, 2015, 2016, 2017, 2018, August 2010, 2012, 2015, 2016, 2017, 2018.

There is an increased skin stress in January and relaxation in March, April, October, November (fig. 4). In a very cold, strong wind, the stress index of the skin can reach high levels of wind cooling power, causing a very high hypertonic stress with implications for the health of the exposed person (fig. 4), which can cause rapid frostbite of parts of the unprotected human body exposed to direct air.
Temperature equivalent to wind cooling $T_{\text {}}$

Tpr values ranging from 0 to 3.5 were in ${ }^{p}$ December and January throughout the analyzed period, the stress is expressed by the trend of dehydration in winter. $T$ index values ranging from 4 to 7 were in March throughout the analyzed period, the stress is expressed by the tendency to dehydrate during cold weather. Balance values were obtained in February, March 2016, November, December 2017, December 2015, 2015, 2017 (8.9-11.7). Values between 11.7-15.5 hydration in April 2009, 2010, 2011, 2013, 2014, 2015, October 2009, 2011, 2013, 2016, November 2015, 2017. In the other months of May -

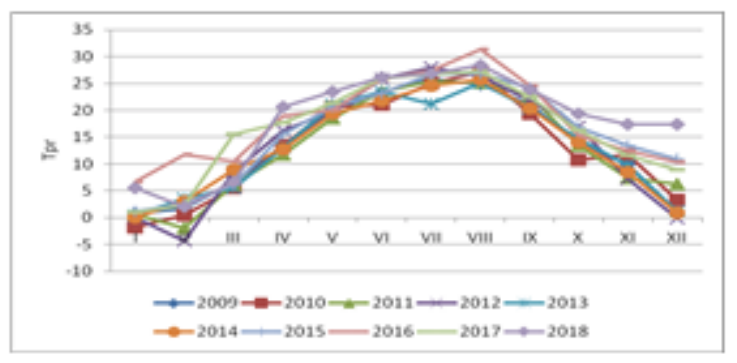

Fig. 5 Values obtained for Tpr in the years 2009-2018

September all the analyzed period obtained values corresponding to the hydration according to table 3 and figure 5.

\section{Conclusions}

The analysis of the different comfort indices shows that the bioclimatic conditions for Bucharest are comfortable. Based on daily data, summer is very pleasant for tourists, for residents except for some warm summer months when it was a moderate discomfort.

In the winter months, values were found to be consistent with discomfort and moderate discomfort. According to the skin stress index during the summer, the prevailing values are between 150-299 corresponding to the stress by triggering thermolysis, exerting on the human body a slight discomfort, which requires heat loss. There is an increased skin stress in J anuary and relaxation in March, April, October, November. In a very cold, strong wind, the skin's stress index can reach a high level of wind cooling power, causing a very high hypertonic stress with implications for the health of the exposed person, which can quickly cause frostbite of body parts unprotected human exposed to direct atmospheric air. Skin stress is low, about half of the year presenting a relaxing climate from this point of view. Hypotonic stress, triggering summer thermolysis, is felt mostly in July and August. The temperature equivalent to the wind cooling pow er ran for the April - October period as one characterized by thermal comfort; only J anuary, the month with the low est average temperature and moderate wind speeds, is characterized by more discomfort. 


\section{References}

1. SCHARLAU, K., Einführung eines Schwülemasstabes und Abgrenzung von Schwülezonen durch Isohygrothermen, Erdkunde, v.4, p.188-201, 1950.

2. KYLE, W.J., CHANG, C.P., Proc. the $2^{\text {nd }}$ Int. Conference on East Asia and Western Pacific Meteorology and Climate, Hong Kong.World Scientific, 557-583, 1992.

3. IONAC, N., CIULACHE, S., Present environment and sustainable development, 1, 168-178, 2007.

4. BISTRICEAN, P.I., MIHẪLÃ, D., LAZURCA, G. L., 11, 1, Bioclimatic regionalization of Moldova west of the Prut river, pp. 45-55, 2017.

5. IONAC, N., CIULACHE, S., Present environment and sustainable development, 1, pp. 168-178, 2007.

6. UNGER, J. Comparisons of urban and rural bioclimatological conditions in the case of a Central-European city. Int. J. Biometeorology, 43, 139-144, 1999.

7. RUSANESCU, C.O., RUSANESCU, M., IORDANESCU, T., ANGHELINA, FL. V., Optoelectron. Adv. Mater. 15, 7-8, 718-723, 2013.

8. THOM E. C., Weatherwise 12, 57-60, 1959.

9. TOY S, S. YILMAZ AND H. YILMAZ. Building and Environment 42 , 1315-1318, 2007.

10. RUSANESCU, C.O., JINESCU, C., RUSANESCU, M., ENESCU, M. C., ANGHELINA, F. V. STOIAN, E.V., DESPA, V., Mat. Plast., 54, 3, 409-413, 2017.

11. TAWHIDA A. YOUSIF, HISHAM M. M. TAHIR, J OURNAL OF FOREST PRODUCTS \& INDUSTRIES, 2(5), 36-38, 2013.

12. RUSANESCU, C. O., RUSANESCU, M., J. Min. Metall. Sect. B-Metall., 49, 3, B $353-356,2013$.

13. YILMAZ, S., Atmosfera, 20, 3, 2007.

14. Kyle, WJ, Proceedings of the Contemporary Climatology Conference, Brno. TISK LITERA, Brno., 345-350, 1994.

15. JÁNOS UNGER, Int J Biometeorol, 43, 139-144,1999.

16. ANGHELINA, F. V., UNGUREANU, D. N., POPA, C., STOIAN, E. V., POPESCU, I. N., ENESCU, C. M., ANGHELINA, C., The Scientific Bulletin of VALAHIA University MATERIALS and MECHANICS, Vol. 16, No. 15, pp. 21-24, 2018.
17. RUSANESCU, C. O., JINESCU, C., RUSANESCU, M., BEGEA, M., GHERMEC, 0., Rev. Chim. (Bucharest), 69, no. 1, 2018, p. 105-111

18. RUSANESCU, M., PURCAREA, A. A., RUSANESCU, C.O., Conference: $6^{\text {th }}$ International Conference on Management and Industrial Engineering - ICMIE, 395-400, 2013.

19. VLADUT, A., TEODOREANU, E., Bioclimatologie umanã, 216, 2002. 20. IONAC, N., CIULACHE, S., The bioclimatic atlas of Romania, 2008. 21. IOJA I., Methods and techniques for assessing the quality of the environment in the metropolitan area of Bucharest, 2009

22. RUSANESCU C.O., POPESCU I. N., DAVID L., 3 rd International Conference on Environmental and geological science and Engineering (EG' 10), 175-180, 2010

23. BESANCENOT J. P., Premieres donnees sur les stress bioclimatiques moyens en France, Annales de Geographie. Paris, 83, 459, 497-530, 1974.

24. TEODOREANU, E., MIHAILA, D., Present environment and sustainable development, 6, 1, 229-251, 2012.

25. SIPLE, P. A., PASSEL, C. F., Measurements of dry atmospheric cooling in subfreezing temperatures. Proc. Amer. Philos. Soc., 89, 177-199, 1945.

26. RUSANESCU, C. 0., RUSANESCU M., ANGHELINA F. V., BRATU V., Romanian Reports in Physics, 68, 1, 278-293, 2016.

27. PETRE, I. C., CATANGIU, A., POPESCU, I. N., UNGUREANU, D. N., NEGREA, A. D., POINESCU, A. A., ENESCU, M. C., STOIAN, E. V., DESPA, V., The Scientific Bulletin of VALAHIA University MATERIALS and MECHANICS, Vol. 16, No. 15, pp. 17-20, 2018.

28. DESPA, V., ANGHELINA, F. V., IANCU, D., RUSANESCU, C. 0. , JOURNAL OF SCIENCE AND ARTS, YEAR 17, 4, 41, 839-852, 2017.

29. GHERMEC, O., GHERMEC, C., DUBOVAN, S., RUSÃNESCU, C. O., Environmental Engineering and Management Journal, 12, 10, 20192023, 2013.

30. VLADUT, A., NIKOLOVA, N., LICURICI, M., Museum of Oltenia Craiova. Oltenia. Studies and communications. Natural Sciences. Tom 33, No. 1/2017, pp. 154-164.

31. SOHACIU, M. G., NICOLAE, A., GRADINARU, C., NICOLAE, M., U.P.B. Sci. Bull., Series B, Vol. 80, Iss. 4, 2018.

32. DURBACA, A. C., IATAN, R., DURBACA, Ion., DINIA, A., RUSANESCU, C. O., U.P.B. Sci. Bull., Series D, Vol. 80, Iss. 3, 2018.

33. DURBACA, I., Mat. Plast., 52, 1, 43 - 47, 2015.

Manuscript received: 14.12 .2018 